\title{
Land Use/Land Cover and Change Detection Mapping in Binpur- II Block, Paschim Medinipur District, West Bengal: A Remote Sensing and GIS Perspective
}

\author{
Jadab Chandra Halder \\ Research Fellow, Department of Geography, University of Calcutta, India
}

\begin{abstract}
Land use and land cover change have been among the most important perceptible changes taking place around us. Although the magnitude, variety and spatial heterogeneity of changes taking place have made the quantification and assessment of land use and land cover changes a challenge to scientists [1]. Information on land uselland cover in the form of maps and statistical data is very important for spatial planning, management and utilization of land. With the changing times and increasing demand on the availability of information on land use/land cover, it becomes necessary to have a standard classification system, precise definition on land use/land cover and its categories, uniform procedures of data collection and mapping on different scales over Indian region [2]. Remote Sensing and Geographical Information Systems (GIS) are the essential tools in assessing and analyzing land use/land cover changes. These tools also provide the synoptic information on land uselland cover, mapping of land use spatial distribution and the detection of changes by means of multi-temporal analysis. This article seeks to examine the distribution of different land use/land cover categories and their changes occurring from 1970-1971 to 2010-2011, trend in land use/land cover changes in Binpur-II block, Paschim Medinipur district, West Bengal (Fig. 1). The importance of Remote Sensing and GIS techniques in mapping the change detection has also highlighted.
\end{abstract}

Key Words: Change detection, Land cover, Land use, Remote Sensing and GIS, Trend in land use/land cover changes.

\section{Introduction:}

Land is the stage on which all human activities are being conducted and source of the materials need for this conduct [3]. Land is the most significant of all the natural resources and the human-use of land resources gives rise to 'Land use'. Land use varies with the man's activity on land or purpose for which the land is being used, whether it is food production, provision for shelter, recreation and processing of materials and so on, as well as the biophysical characteristics of the land itself. The land use is being shaped under the influence of two broad set of forces viz. human needs and environmental processes. In the developing countries like India, due to population pressure and in a bid to extract the maximum output from the available resources, the impact of degradation can be worse than in other countries and adversely affect the land cover of the region. Hence, land uses have been shaped for centuries by human management, and the structure of the land use has emerged and changed over time and space. In the current century, these changes have accelerated in response to a variety of forces such as agriculture, urbanization etc. Land use and land cover information are important for several planning and management activities concerned with the surface of the earth [4] because it constitutes key environmental information for many scientific, resource management and policy purposes, as well as for a range of human activities [5]. An accurate knowledge of land use and land cover is a key element for any kind development planning of a particular region. Therefore a wide range of scientists and practitioners, including earth system scientists, land and water managers as well as urban planners seek information on the location, distribution, type and magnitude of land use and land cover changes, trend of land use conversion etc. The spatial dimensions of land use and land cover help the policy makers and scientists to take the appropriate decisions, because the changing pattern of land use and land cover reflect changing economic and social conditions. Monitoring such changes is important for coordinated actions at different administrative levels.

Modern technologies such as Remote Sensing and Geographical Information Systems (GIS) provide the most accurate means of measuring the extent and pattern of changes in landscape conditions over time [5] [6]. The specific objectives of the study are 1) to assess whether there have been changes in land use and land cover in Binpur-II block, 2) to quantify the changes in land use and land cover.

\section{Concept of Land Cover and Land Use:}

Central to the subject matter of all land information systems are the concept of land use and land cover. Land cover is the biophysical state of the earth surface [7]. In other words, land cover describes the observed 
physical state of the land surface as seen on the ground at a given location and time. This includes the soil surface, vegetation or forest, cropland, mountains etc [8] [9]. Moser (1996) noted that 'The term 'land cover' originally refers the type of vegetation that cover the earth surface', but he has broadened subsequently to include human aspects of the physical environment, such as soils, biodiversity, surfaces and ground water.

Land use involves both the manner in which the biophysical attributes of the land are manipulated and the intent underlying that manipulation and the purpose for which the land is used [7]. In a similar way Skole (1994) stated that 'Land use is a description of function, the purpose for which is land is being used, i.e. the management of land to meet human needs' [10]. Meyer and Turner (1994) stated that 'Land use is the way in which, and the purpose of which, human beings employ the land and its resources [11]. Finally FAO (1995) stated the following definition of land use:

"A series of operations on land, carried by humans, with the intention to obtain products and/or benefits through using land resources" [12].

From the above definition, land use types can be described in terms of series of activities and their associated inputs and outputs. A land use may take place on one or more than one piece of land, and several land uses may occur on the same piece of land. For example, the changing nature of agricultural activities in respect to changing nature of season give birth the different croplands on a single piece of land.

From the discussion it may be summarized that land cover and land use are not equivalent although they may overlap. By land cover is meant the physical, chemical, or biological categorization of the terrestrial surface, where as land use refers to the purposes that are associated with that cover.

However the distinction between land use and land cover, although easy to make at a conceptual level, is not so straight forward in practice. At the global level, key sources of data do not distinguish clearly between cover and use [11] [8].

\section{Land Use Classification Scheme:}

The analysis of land use change depends critically on the chosen system of land use and land cover classification. The development of land use classification system has a long history in various countries of the world. At the world scale, the first land use/land cover classification system produced concerned to the major land uses of the world. The FAO produced the first land use statistics during 1950s, using a '4-category' classification of land use: arable land (crop land), grass land (permanent pasture), forest land and other land (urban areas, unmanaged range land, polar region, desert land stony and rocky land) [13] [3]. At the sub global level, mostly the national level, several land use classification systems are in use. In USA the US Geological Survey (USGS) has developed the land use and land cover classification system for use with remotely sensed data [14], which is widely used by remote sensing community as well as different scientists, concerned organizations who are involved in mapping of earth surface features [15].

At present there is no standard classification system in India and a very few organizations like National Atlas and Thematic Mapping Organization (NA\&TMO), Directorate of Economics and Statistics etc. have developed their own classification schemes for land use mapping. Although the Technical Committee on Coordination of Agricultural Statistics (TCCAS) in 1950 recommended standard classification scheme, which is adopted by the states all over the India [16].

There have changes in the categories of land use/land cover during the two study years. The land use categories have been expanded in the second study year (2010-2011). For instance in 1970-1971, there was no sub classification of arable land, but in 2010-2011 arable land has classified as fallow land and net sown area. Therefore it is difficult to compare the land use pattern of 1970-1971 with that of 2010-2011. But for the comparison purposes, the land use of 1970-1971 has taken into consideration. The land use data of 1970-1971 have been generated from the topographical sheets, where as the land use data of 2010-2011 have been generated from LISS-III images through more sophisticated techniques (Fig. 2). Therefore for comparative purposes, in this paper land use categories have been reclassified in to four broad categories (Table. 1).

\section{Study Area:}

The study area i.e. Binpur-II block is situated in the extreme northwestern part of the Paschim Medinipur district (West Bengal), between $22^{\circ} 32^{\prime} 42^{\prime \prime} \mathrm{N}$ to $22^{\circ} 48^{\prime} 49^{\prime \prime} \mathrm{N}$ Latitude and $86^{\circ} 33^{\prime} 50^{\prime \prime} \mathrm{E}$ to $86^{\circ} 59^{\prime} 23^{\prime \prime} \mathrm{E}$ Longitude and encompasses an area of $583.50 \mathrm{sq}$. $\mathrm{Km}$. The block is divided into ten Gram Panchayats and 470 revenue villages (Fig. 1).

Physiographically Binpur-II block is subdivided into two divisions, viz. plateau proper area and plateau fringe area. Plateau proper area covers particularly the north western part of the block where it is in juxtaposition with Pre-Cambrian shield of Singhbhum district, Jharkhand and Purulia and Bankura districts of West Bengal. This area is extremely rugged in nature and sometimes is capped by laterites. The approximate lower limit of this plateau proper area is indicated by 156 meter [17]. The land is highest elevation of 494 meter above mean sea level is observed near Kankrajhore in this topographic region. Further east of the plateau proper 
region is characterized by laterite covered platform sediments of Tertiary and Pleistocene age. This region is generally flatter and rolling in nature.

\section{Data Source:}

The relevant topographic sheets (No. 73J/9, 10 and 14) published by Survey of India on a scale of 1:50,000 served as one of the data source. Besides digital data of IRS P6, LISS-III (November, 2010) with 23.5mm resolution has been used. The District Census Handbook of 1971 and Agricultural Annual Plan-2011, Paschim Medinipur district have also been consulted [18] [19].

\section{Methodology:}

The present work is involved of following three steps which can be summarized in the form of a Schematic model (Fig. 2).

- The image processing by using Remote Sensing Software ERDAS IMAGINE-9.2.

- Land use/land cover classification by applying supervised classification method.

- Change detection analysis by using overlay operation in ARC GIS-9.3 Software.

\section{Extent of Land Use/Land Cover:}

\section{Results and Discussion:}

The static land use/land cover distribution of each study year as derived from the maps has presented in the Fig. 3, 4 and Table 2. Table 2 shows that the most extensive land use/land cover category of Binpur-II block as at 1970-1971 was arable land, which covered 297.79 sq. Km. (51.04\%). The second most extensive land use category was forest land, which covered $225.87 \mathrm{sq}$. Km. (38.70\%). Area not available for cultivation occupied 38.23 sq. Km. (6.55\%). This was followed by other uncultivated excluding fallow land, which covered 21.62 sq. Km. (3.70\%).

Table 3 and Fig. 5, 6 reveal the magnitude of the spatial extent of the land use/land cover categories for the year of 2010-2011, which is different from that in 1970-1971. With 2010-2011, the most extensive cover being arable land, which covers $294.96 \mathrm{sq} . \mathrm{Km}(50.55 \%)$, Forest land is the second most extensive category in the year of 2010-2011, which covers of an area 216.66 sq. Km. (37.13\%). Area not available for cultivation covers 49.37 sq. $\mathrm{Km}$. (8.46\%), while other uncultivated excluding fallow land covers $22.51 \mathrm{sq} . \mathrm{Km}(3.86 \%)$

\section{Volume of Change in Different Land Use/Land Cover Categories:}

The comparative study of maps for two study years reveal the geographical distribution and changing nature of different land use/land cover categories in the study area, which can be summarized as following manners:

- The area under arable land has decreased from 297.79 sq. Km. in 1970-1971 to $294.96 \mathrm{sq}$. Km. in 20102011 showing a net decrease of 2.83 sq. $\mathrm{Km}$. A spatial analysis of arable land during this period has shown an increase in 3 gram panchayats of the block, out of which a high increase is recorded in Banspahari gram panchayat. A decrease in percentage of arable land also is recorded in 7 gram panchayats of the block, of which Bhulaveda gram panchayat has shown high decrease of over 20\% (Table. 4, Fig. 7 and 8).

- Between 1970-1971 and 2010-2011, the percentage of forest land has decreased by 4.08\%. In terms of areal extent, it has decreased from 225.87 sq. Km. in 1970-1971 to 216.66 sq. Km. in 2010-2011 (Table. 4 , Fig. 9 and 10). The gram panchayat level study reveals that, an increase in forest land has taken place in 2 gram panchayat viz. Silda and Bhulaveda. A decrease in the percentage of area under forest has registered in 7 gram panchayats, out of which Banspahari has shown high decrease (19.39\%).

- Between 1970-1971 and 2010-201, the percentage of other uncultivated excluding fallow land has increased by $4.13 \%$. A spatial analysis reveals that, 8 gram panchayats have shown an increase in other uncultivated excluding fallow land out of which 3 gram panchayats viz. Simulpal, Belpahari and Sandapara have registered high increase i.e. $1029.09 \%, 317.53 \%$ and $263.29 \%$ while 2 gram panchayats (Banspahari and Bheladiha) have shown some decrease (Table. 4 and Fig. 11, 12).

- During this period remarkable changes have occurred in changes of area not available for cultivation which are shown in table. 4 and fig. 13 and 14. The area under this category has increased from 38.23 sq. $\mathrm{Km}$ to $49.37 \mathrm{sq}$. $\mathrm{Km}$. The increase is recorded in 9 gram panchayats of the block while only one gram panchayat (Bhulaveda) is recorded decrease of over $20 \%$.

\section{Trend of Land Use/Land Cover Conversion:}

The mutual conversion among different land use/land cover categories has been shown in Table. 5 and Fig. 15 during 1970-1971 to 2010-2011. The change in the areal extent of a particular category is linked to the change areal extent of one or more categories of the study area. If different land use/land cover categories are considered as different parts of a single system, the each of these units are linked with each other through conversion. A schematic model has prepared for the study area is given in Fig. 16. The model shows that the 
land, converted by arable land has been converted to forest $(22.36 \mathrm{sq} . \mathrm{Km})$ due to social forestry and to area not available for cultivation $(23.39 \mathrm{sq}$. $\mathrm{Km}$ ) due to the different constructional works. Similarly the land converted by forest has been converted to arable land $(22.26 \mathrm{sq} . \mathrm{Km})$ due the improvement of agriculture and to area not available for cultivation ( $3.60 \mathrm{sq}$. Km) due to the increasing demand of land for settlements. Besides, the mutual conversions between arable land and other uncultivated excluding fallow land (9.40 sq. Km and $9.33 \mathrm{sq} . \mathrm{Km}$ ) and between area not available for cultivation and other uncultivated excluding fallow land (2.14 sq. Km and $2.37 \mathrm{sq} . \mathrm{Km}$ ) are not remarkable. Land use/land cover conversion has taken place of an area about 121.25 sq. $\mathrm{Km}$, which account for $20.78 \%$ of the total area, over 40 years period.

\section{Figures and Tables:}

Location Map of the Study Area

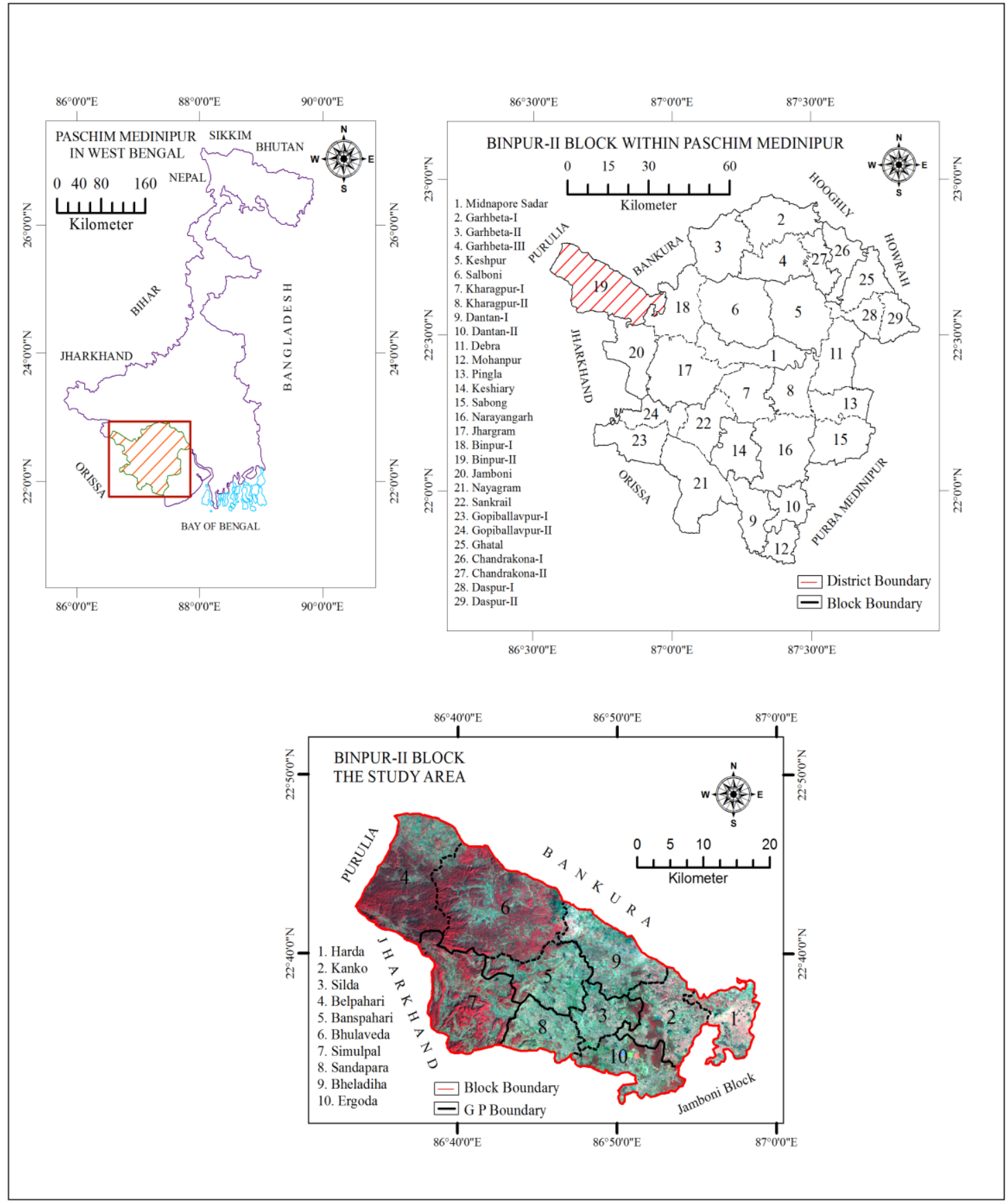

figure. 1 
Schematic Model of Methodology

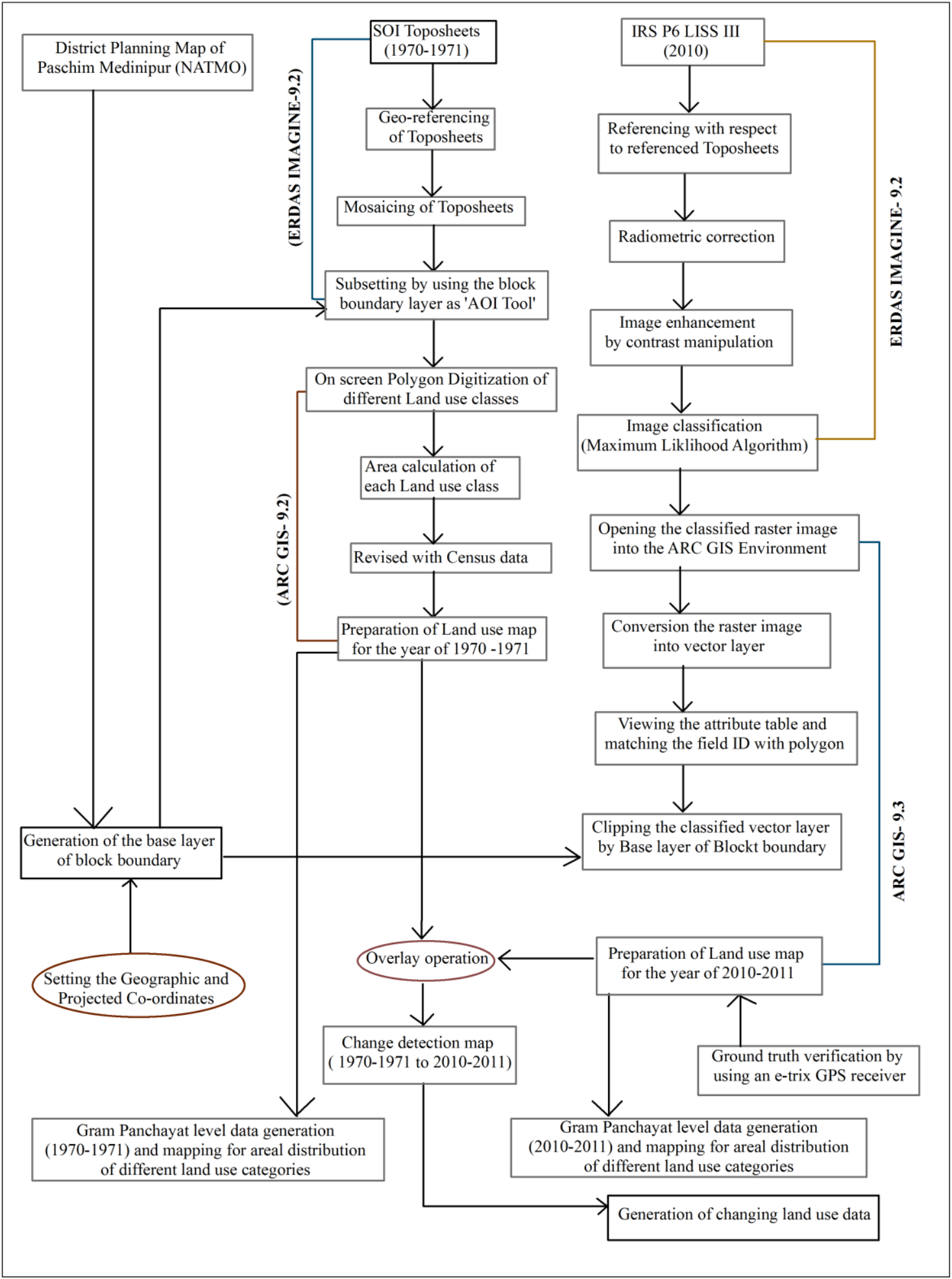

figure. 2 


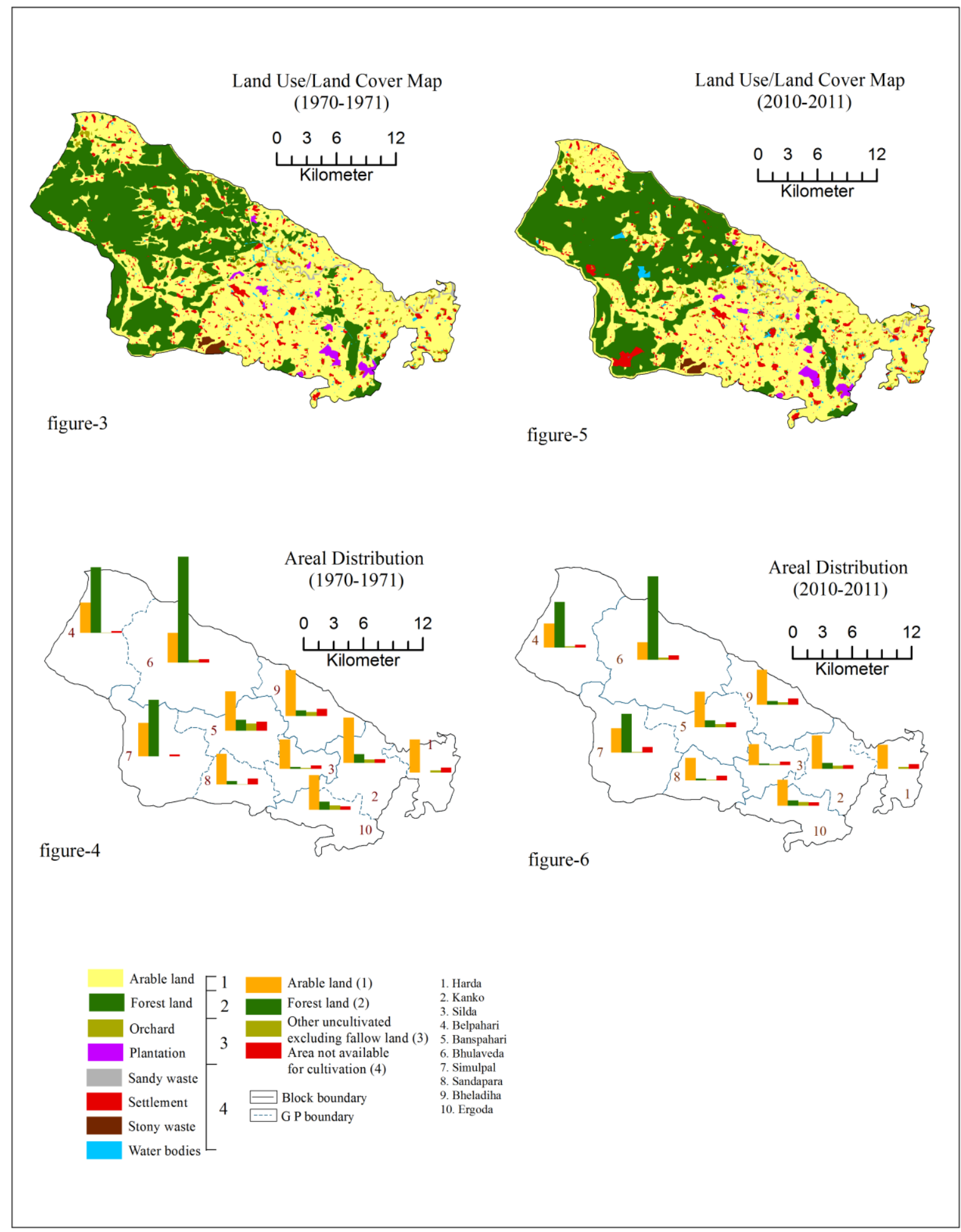


Changing Pattern of Arable Land

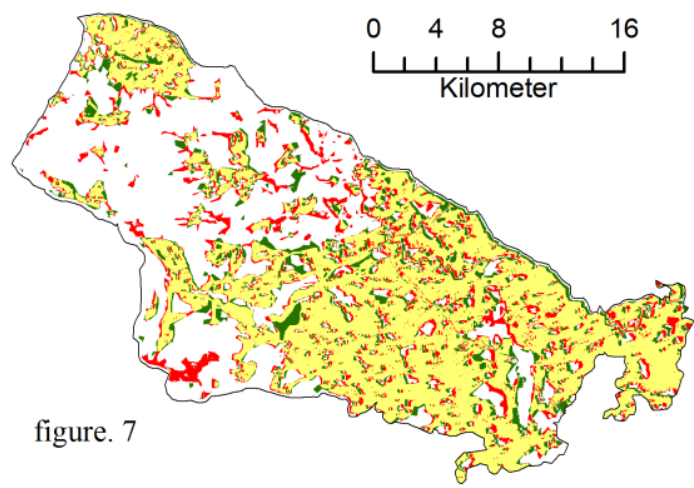

Changing Pattern of Forest Land

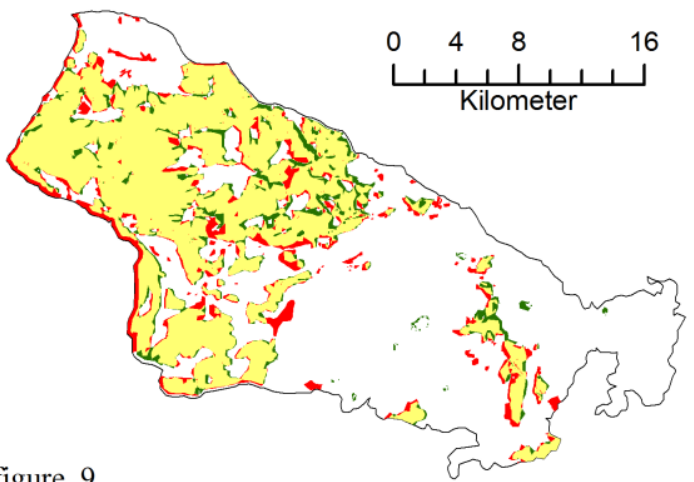

figure. 9
Volume of Change in Arable Land

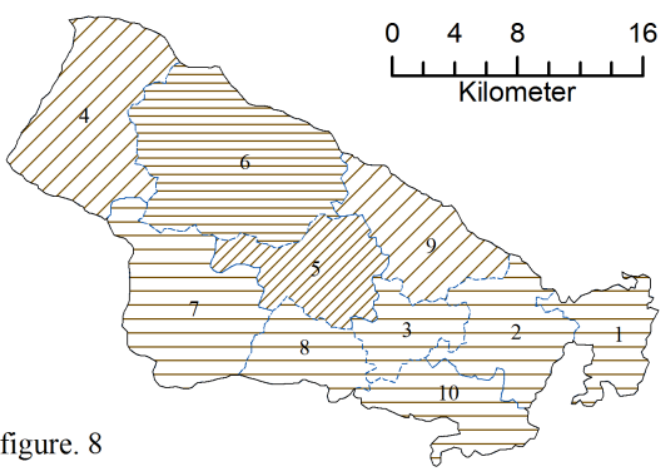

Volume of Change in Forest Land

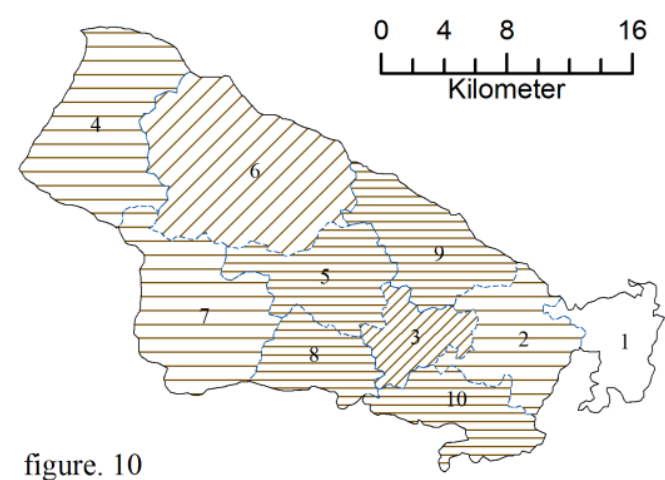

figure. 10

Volume of change in \%

Positive change 2. Kank

Negative change 3. Silda

No change 4. Belpahari

5. Banspahari

6. Bhulaved

Block boundary

7. Simulpal

8. Sandapara

10. Ergoda

Increase

Decrease

G P boundary

Z7 < 10

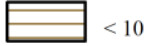

DID 20-30 E $20-30$ 
Changing Pattern of Other uncultivated Excluding Fallow Land

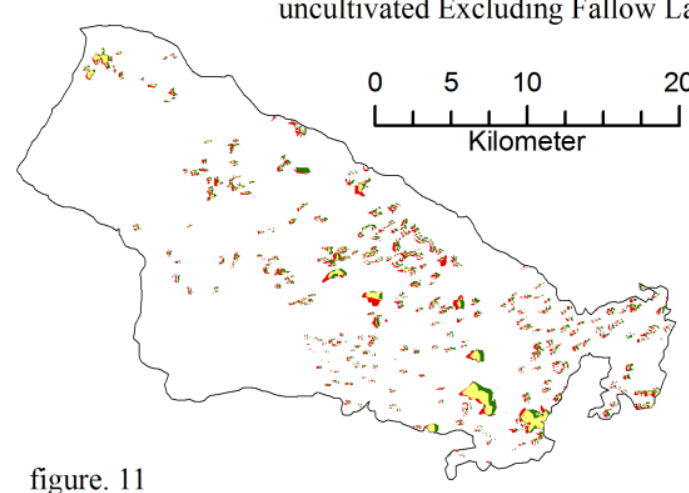

figure. 11

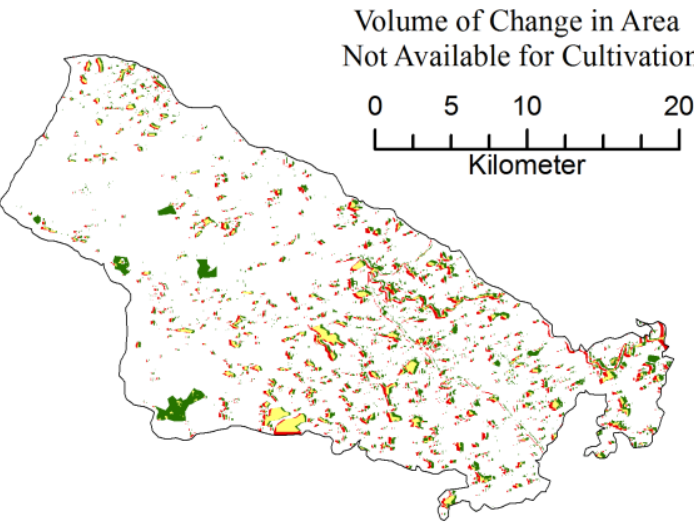

figure. 13
Volume of Change in Other uncultivated Excluding Fallow Land

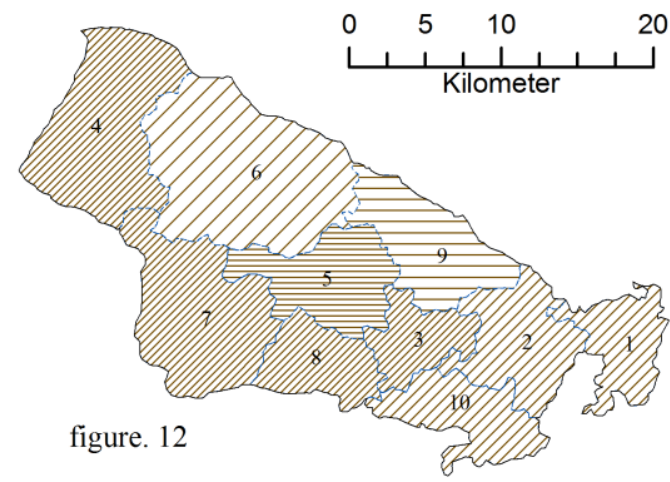

figure. 12

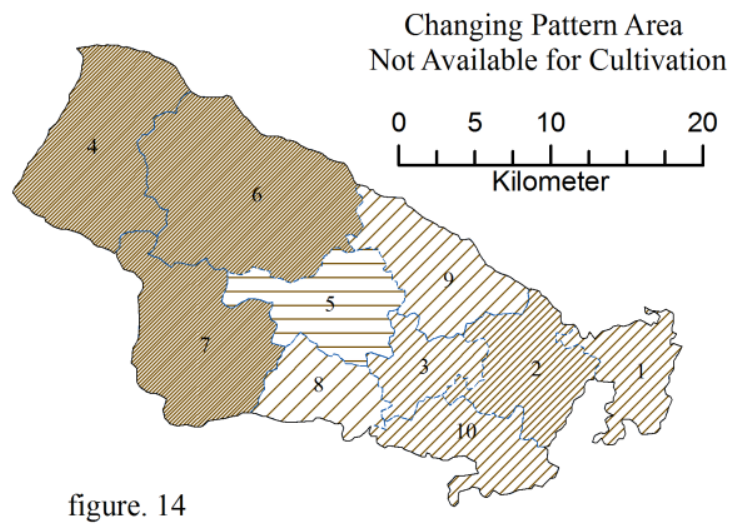

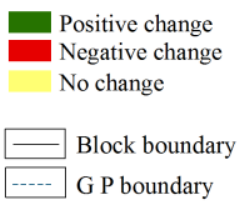

1. Harda

Kanko

. Silda

4. Belpahari

5. Banspahari

6. Bhulaveda

7. Simulpal

8. Sandapara

9. Bheladiha

10. Ergoda

Volume of change in \%

Increase

Decrease

P/ $<10$ ए $10-20$

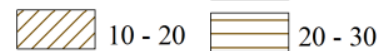

QVIV 20-30 五竖 $>40$

$>40$ 


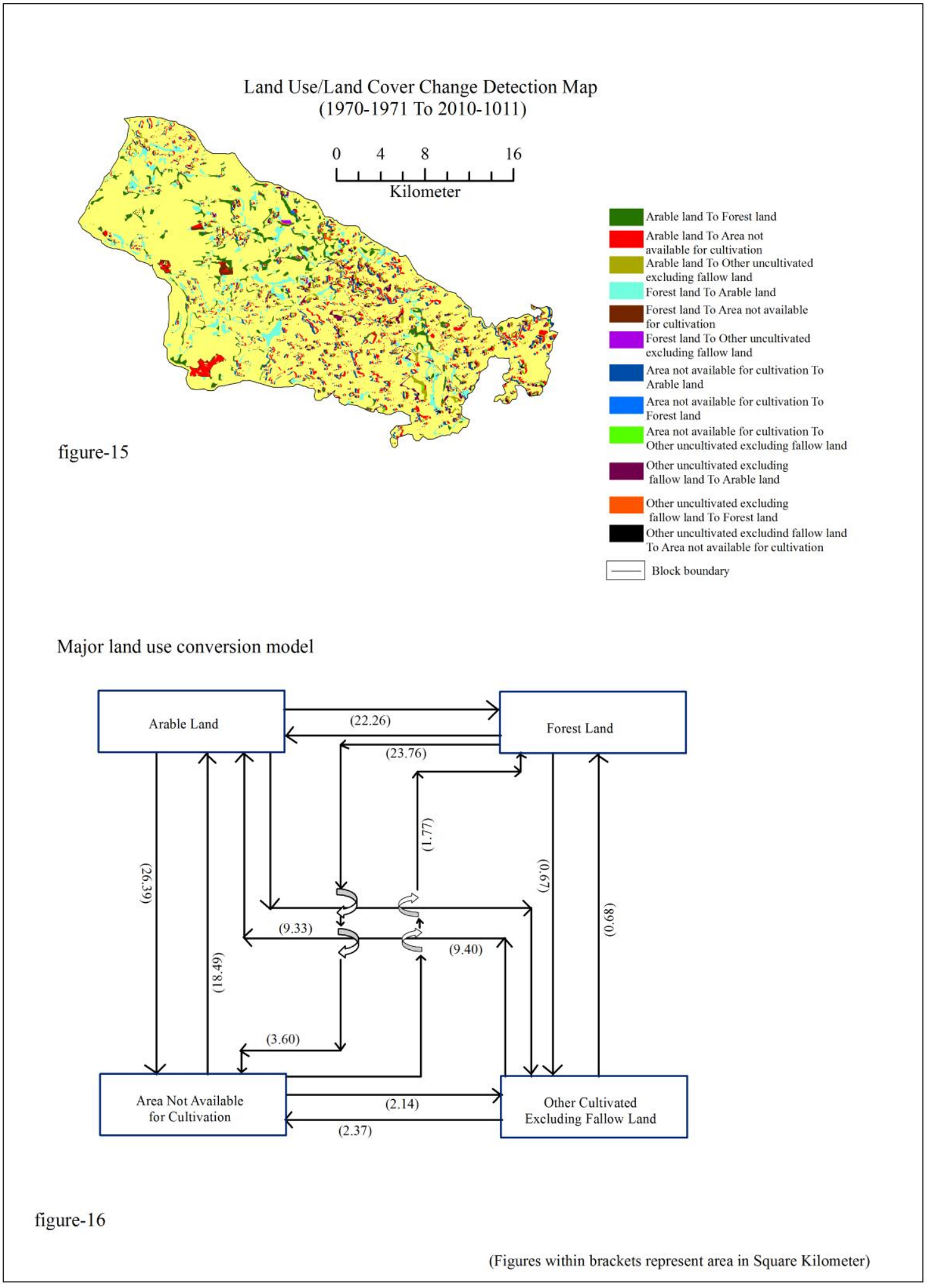


Table: 1

Classification Scheme of Land Use/Land Cover adopted for the present study

\begin{tabular}{l|l}
\hline \multicolumn{1}{c|}{$\begin{array}{c}\text { Level-I } \\
\text { (Macro/Broad - Categories) }\end{array}$} & \multicolumn{1}{c}{\begin{tabular}{c}
\multicolumn{1}{c}{ Level- II } \\
(Meso- Categories)
\end{tabular}} \\
\hline \multirow{3}{*}{ 1. Forest Land } & 1.1. Dense Forest \\
& $\begin{array}{l}\text { 1.2. Open Forest } \\
\text { 1.3. Scrub Land and Bushes } \\
\text { 2.1. Fallow Land }\end{array}$ \\
& 2.2. Net Sown Area \\
& 3.1. Permanent Pasture and Other Grazing \\
3. Other Uncultivated Excluding & 3.2. Land Under Miscellaneous Tree Crops and \\
Fallow Land & Groves \\
& 3.3. Orchard and Plantation \\
& 3.4. Cultivable Waste Land \\
& 4.1. Settlement Area \\
4. Area Not Available for Cultivation & 4.2. Area Under Water \\
& (Waste Land) \\
& 4.4. Road and Railways \\
\hline
\end{tabular}

Source: Directorate of Economics and Statistics, Ministry of Agriculture, Government of India, 2002 [21] Anderson Land Use Classification System, 1976 [14]

Table-2

Land Use Pattern of Binpur-II Block, Paschim Medinipur in 1970-1971 (Area in Square Kilometer)

\begin{tabular}{|c|c|c|c|c|c|c|}
\hline $\begin{array}{l}\text { Sl. } \\
\text { No }\end{array}$ & Name of G.P & $\begin{array}{l}\text { Arable } \\
\text { Land }\end{array}$ & Forest Land & $\begin{array}{c}\text { Other Uncultivated } \\
\text { Excluding Fallow } \\
\text { Land }\end{array}$ & $\begin{array}{c}\text { Area not available for } \\
\text { cultivation }\end{array}$ & Total Area \\
\hline 1 & Harda & 27.96 & 0.00 & 1.77 & 4.16 & 33.89 \\
\hline 2 & Kanko & 38.34 & 7.39 & 2.82 & 3.14 & 51.69 \\
\hline 3 & Silda & 24.85 & 1.68 & 0.75 & 3.00 & 30.29 \\
\hline 4 & Belpahari & 25.72 & 55.68 & 0.34 & 1.60 & 83.34 \\
\hline 5 & Banshpahari & 33.34 & 9.23 & 6.07 & 7.66 & 56.30 \\
\hline 6 & Bhulaveda & 25.26 & 89.60 & 2.25 & 3.01 & 120.13 \\
\hline 7 & Simulpal & 28.16 & 47.82 & 0.06 & 1.69 & 77.72 \\
\hline 8 & Sandapara & 25.72 & 2.71 & 0.24 & 4.97 & 33.63 \\
\hline 9 & Bheladiha & 39.05 & 4.83 & 3.47 & 6.08 & 53.42 \\
\hline 10 & Ergoda & 29.37 & 6.93 & 3.86 & 2.91 & 43.06 \\
\hline \multicolumn{2}{|r|}{ Block Total } & 297.79 & 225.87 & 21.62 & 38.23 & 583.50 \\
\hline
\end{tabular}

Computed by author

Table-3

Land Use Pattern of Binpur-II Block, Paschim Medinipur in 2010-2011

(Area in Square Kilometer)

\begin{tabular}{|c|c|c|c|c|c|c|}
\hline $\begin{array}{l}\text { Sl. } \\
\text { No }\end{array}$ & Name of G.P & $\begin{array}{c}\text { Arable } \\
\text { Land }\end{array}$ & Forest Land & $\begin{array}{c}\text { Other Uncultivated } \\
\text { Excluding Fallow } \\
\text { Land }\end{array}$ & $\begin{array}{c}\text { Area not } \\
\text { available for } \\
\text { cultivation }\end{array}$ & Total Area \\
\hline 1 & Harda & 29.69 & 0.00 & 2.11 & 5.09 & 33.89 \\
\hline 2 & Kanko & 37.41 & 6.77 & 3.38 & 4.13 & 51.69 \\
\hline 3 & Silda & 23.50 & 1.90 & 1.12 & 3.77 & 30.29 \\
\hline 4 & Belpahari & 27.10 & 51.33 & 1.42 & 3.49 & 83.34 \\
\hline 5 & Banshpahari & 39.88 & 7.44 & 3.36 & 5.62 & 56.30 \\
\hline 6 & Bhulaveda & 19.46 & 93.42 & 2.45 & 4.80 & 120.13 \\
\hline 7 & Simulpal & 27.40 & 43.39 & 0.62 & 6.31 & 77.72 \\
\hline 8 & Sandapara & 25.30 & 2.23 & 0.86 & 5.24 & 33.63 \\
\hline 9 & Bheladiha & 39.24 & 4.25 & 2.84 & 7.09 & 53.42 \\
\hline 10 & Ergoda & 28.94 & 5.93 & 4.34 & 3.85 & 43.06 \\
\hline \multicolumn{2}{|r|}{ Block Total } & 294.96 & 216.66 & 22.51 & 49.37 & 583.50 \\
\hline
\end{tabular}

Computed by author 
Table: 4

Volume of Change in Different Land Use Categories in Binpur-II (1970-1971 to 2010-2011)

\begin{tabular}{|c|c|c|c|c|c|c|c|c|c|}
\hline \multirow{2}{*}{ Sl. No } & \multirow{2}{*}{$\begin{array}{l}\text { Name of } \\
\text { Block }\end{array}$} & \multicolumn{2}{|c|}{ Arable Land } & \multicolumn{2}{|c|}{ Forest Land } & \multicolumn{2}{|c|}{$\begin{array}{c}\text { Other Uncultivated } \\
\text { Excluding Fallow } \\
\text { Land }\end{array}$} & \multicolumn{2}{|c|}{$\begin{array}{l}\text { Are not available } \\
\text { for cultivation }\end{array}$} \\
\hline & & $\begin{array}{l}\text { Area in } \\
\text { Sq. km }\end{array}$ & $(\%)$ & $\begin{array}{l}\text { Area } \\
\text { in Sq. } \\
\mathrm{km}\end{array}$ & $(\%)$ & $\begin{array}{l}\text { Area in } \\
\text { Sq. km }\end{array}$ & $(\%)$ & $\begin{array}{l}\text { Area in } \\
\text { Sq. km }\end{array}$ & $(\%)$ \\
\hline 1 & Harda & -1.27 & -4.53 & 0.00 & 0.00 & 0.34 & 19.24 & 0.93 & 22.27 \\
\hline 2 & Kanko & -0.93 & -2.42 & -0.62 & -8.39 & 0.56 & 19.88 & 0.99 & 31.41 \\
\hline 3 & Silda & -1.35 & -5.43 & 0.22 & 13.10 & 0.37 & 48.74 & 0.76 & 25.40 \\
\hline 4 & Belpahari & 1.38 & 5.38 & -4.35 & -7.81 & 1.08 & 317.53 & 1.89 & 117.82 \\
\hline 5 & Banshpahari & 6.54 & 19.62 & -1.79 & -19.39 & -2.71 & -44.63 & -2.04 & -26.67 \\
\hline 6 & Bhulaveda & -5.80 & -22.96 & 3.82 & 4.26 & 0.20 & 8.76 & 1.78 & 59.16 \\
\hline 7 & Simulpal & -0.75 & -2.67 & -4.43 & -9.26 & 0.57 & 1029.09 & 4.62 & 272.96 \\
\hline 8 & Sandapara & -0.41 & -1.61 & -0.48 & -17.71 & 0.62 & 263.29 & 0.27 & 5.43 \\
\hline 9 & Bheladiha & 0.20 & 0.50 & -0.58 & -12.01 & -0.63 & -18.06 & 1.01 & 16.62 \\
\hline 10 & Ergoda & -0.42 & -1.44 & -1.00 & -14.43 & 0.48 & 12.55 & 0.94 & 32.32 \\
\hline \multicolumn{2}{|c|}{ Block Total } & -2.83 & -0.95 & -9.21 & -4.08 & 0.89 & 4.13 & 11.14 & 29.15 \\
\hline
\end{tabular}

Table-5

Land Use Conversion in Binpur-II Block, Paschim Medinipur District (1970-1971 to 2010-2011)

\begin{tabular}{|c|c|c|c|}
\hline \multicolumn{2}{|c|}{ Land Use Conversion } & \multirow[b]{2}{*}{$\begin{array}{c}\text { Area Change } \\
\text { (Square Kilometer) }\end{array}$} & \multirow[b]{2}{*}{ Percentage Change } \\
\hline $\begin{array}{c}\text { From } \\
(1970-1971)\end{array}$ & $\begin{array}{c}\text { To } \\
(2010-2011)\end{array}$ & & \\
\hline Arable Land & Area Not Available for Cultivation & 26.39 & 21.76 \\
\hline Arable Land & Forest Land & 22.26 & 18.36 \\
\hline Arable Land & $\begin{array}{l}\text { Other Uncultivated Excluding } \\
\text { Fallow Land }\end{array}$ & 9.40 & 7.75 \\
\hline Forest Land & Arable Land & 23.76 & 19.60 \\
\hline Forest Land & Area Not Available for Cultivation & 3.60 & 2.97 \\
\hline Forest Land & $\begin{array}{c}\text { Other Uncultivated Excluding } \\
\text { Fallow Land }\end{array}$ & 0.67 & 0.55 \\
\hline $\begin{array}{l}\text { Area Not Available for } \\
\text { Cultivation }\end{array}$ & Arable Land & 18.49 & 15.25 \\
\hline $\begin{array}{l}\text { Area Not Available for } \\
\text { Cultivation }\end{array}$ & Forest Land & 1.77 & 1.46 \\
\hline $\begin{array}{c}\text { Area Not Available for } \\
\text { Cultivation }\end{array}$ & $\begin{array}{l}\text { Other Uncultivated Excluding } \\
\text { Fallow Land }\end{array}$ & 2.14 & 1.76 \\
\hline $\begin{array}{l}\text { Other Uncultivated Excluding } \\
\text { Fallow Land }\end{array}$ & Arable Land & 9.33 & 8.02 \\
\hline $\begin{array}{l}\text { Other Uncultivated Excluding } \\
\text { Fallow Land }\end{array}$ & Area Not Available for Cultivation & 2.37 & 1.95 \\
\hline $\begin{array}{c}\text { Other Uncultivated Excluding } \\
\text { Fallow Land }\end{array}$ & Forest Land & 0.68 & 0.56 \\
\hline $\begin{array}{ll}\text { Blo } \\
\end{array}$ & Total & 121.25 & 100.00 \\
\hline
\end{tabular}

Compute by author

\section{Conclusion:}

The analysis of topographical sheets of 1970-1971, LISS-III image of 2010 reveals that land use/land cover of Binpur-II block has changed over the years. Remote Sensing and GIS systems have the capability for repetitive coverage, which is very helpful in change detection studies. For ensuring planned development and monitoring the land utilization patters, preparation of land use and land cover map is very necessary [20]. This research demonstrates the ability of GIS and Remote Sensing in capturing spatio-temporal data. The land use and land cover categories have produced for each study year. It is expected to be useful for formulating meaningful plans and policies so as to achieve a balanced and sustainable development in the region. This will also help in maintaining the ecological balance and improvement in micro environment of the study area. 


\section{References:}

[1] P.S. Roy, and A. Roy, Land use and land cover change in India: A Remote Sensing and GIS perspective, Journal of the Indian Institute of Science, 90 (4), 2010, 489-502.

[2] P.S. Roy, and A. Giriraj, Land use and land cover analysis in Indian context, Journal of Applied Science, 8 (8) 2008, 1346-1353.

[3] H. Briassoulis, Analysis of Land Use Change: Theoretical and Modeling approach, The web book of Regional Science, Regional Research Institute, West Virginia University, USA, 1999

[4] T.M. Lillesand, and R. Kiefer, Remote Sensing and Image Interpretation, 5 (John Wiley, Inc, New York, 1993).

[5] E. Boayke, S.N. Odai, , K.A. Adjei, and F.O. Annor, Landsat Images for Assessment of the Impact of Land Use and Land Cover Changes on the Barekese Catchment in Ghana, European Journal of Scientific Research, 22 (2), 2008, 269-278.

[6] A.B. Miller, E.S. Bryant, and R.W. Birnie, An analysis of land cover changes in the Northern forest of New England using multitemporal LANDSAT-MSS data, International Journal of Remote Sensing, 19 (2), 1998, 113-130.

[7] B.L.II. Turner, D.L. Skole, S. Sanderson, G. Fischer, L. Fresco, and R. Leemans, Land Use and Land Cover Change, Science/Research Plan, IGBP Report No. 35, HDP Report No. 7, IGBP and HDP, Stockholm and Geneva,1995.

[8] W.B. Meyer, and B.L.II. Turner, Land use/ Land cover change: Challenges for geographers, Geo-journal, 39 (3), $1996,237-240$.

[9] S.C. Moser, A Partial Instructional Module on Global and Regional Land Use/Land Cover Change: Assessing the Data and Searching for General Relationships, Geojournal, 39 (3), 1996, 241-283.

[10] D.L. Skole, Data on Global Land-Cover Change: Acquisition, Assessment and Analysis, in W.B. Meyer, and B.L.II. Turner (Eds.), Changes in Land Use and Land Cover: A Global Perspective, (Cambridge: Cambridge University, 1994) 437-471.

[11] W.B. Meyer, and B.L. II. Turner, Changes in Land Use and Land Cover: A Global Perspective (Cambridge, Cambridge University, 1994)

[12] Food and Agriculture Organization (FAO), Planning for Sustainable Use of Land Resources, FAO Land and Water Bulletin 2, (Rome, FAO of the United Nations)

[13] M.G. Wolman, Criteria for Land Use, in D.J. McLaren, and B.J. Skinner (Eds.), Resource and World Development (New York: John Wiley1987) 643-657

[14] J.R. Anderson, E.E. Hardy, J.T. Roach, and R.E. Witmer, A Land Use and Land Cover Classification System for Use with Remote Sensor Data, U.S Geological Survey Professional Paper- 964, (USGS: Washington, D.C.), 1976

[15] S.K. Yadav, and S.P. Mishra, Land use/ Land cover Change Detection Using Remote Sensing and GIS Techniques- A case study of Mirzapur district, Uttar Pradesh, Indian Journal of Landscape and Ecological Studies, 32 (1), 2009, 300-309.

[16] Y.V Ramanaiah, and N.B.K. Reddy, Land Use Pattern and Dynamics of Land Use in Andhra Pradesh, in B.N Mishra (Ed), Land Utilization and Management in India, (Allahabad, India: Chugh, 1990) 37-62

[17] K. Bagchi, and K.N. Mukherjee, Diagnostic Survey of Rarh Bengal (Kolkata: Department of Geography, 1979)

[18] Directorate of Census Operations, West Bengal 1971), District Census Handbook, Midnapore, 1971, Series.22, Part. X-A, West Bengal, 1971.

[19] Department of Agriculture, Govt. of West Bengal, Annual Plan-2010-2011, Office of the Deputy Director of Agriculture, Paschim Medinipur, 2011.

[20] A.S. Saxena, and R. Agrawal, Change Detection of Land Use and Land Cover Patterns: A Case Study of Mandideep and Obedullaganj in Madhya Pradesh, ITPI Journal, 5 (4), 2008 65-72. 